Scientia studia, São Paulo, v. 11, n. 2, p. 3०5-31, 2013

\title{
त्री \\ Sobre as relações históricas entre a física e a metafísica na obra de Pierre Duhem
}

Fábio Rodrigo Leite

\begin{abstract}
电
RESUMO

No presente artigo, procuramos mostrar, por intermédio de numerosos exemplos, que a distinção lógica operada por Pierre Duhem entre a física e a metafísica não impossibilita que, do ponto de vista histórico, o autor reconheça a existência de um entrosamento profícuo a cingir as duas áreas do saber. Distinguimos três níveis possíveis de interação entre a física e a metafísica, porque acreditamos que ele aceita (a) que o físico trabalha constantemente movido por ambições metafísicas não autorizadas pela rigorosa lógica, (b) que os sistemas metafísicos contribuíram para muitos dos progressos das teorias físicas, em especial, para o nascimento da ciência moderna e (c) que podemos identificar tradições metafísicas de pesquisa duradouras que se mostraram mais férteis do que algumas tradições positivas.
\end{abstract}

Palavras-chave • Duhem. Física. Metafísica. Metodologia. História da ciência. Historiografia.

\section{INTRODUÇÃO}

A complexidade da obra historiográfica de Duhem garantiu a persistência dos debates que se levantaram nas décadas seguintes à sua publicação. Boa parte da polêmica obteve repercussão devido à natureza original e controversa de suas teses, as quais ainda têm gerado discussões minuciosas sobre aspectos particulares relativos à ciência medieval e seu nascimento. Mas outra parte da polêmica, não menos relevante, adveio de uma interpretação resultante de uma leitura um tanto parcial que não leva em consideração a amplitude das questões históricas presentes no decurso das obras de nosso autor. Tem sido quase que uma constante a imputação à obra duhemiana de uma simplificação histórica excessiva, ocasionada, entre outras coisas, pela exclusão indevida das influências metafísicas na história da física. Que esta qualificação seja incorreta é o que pretendemos mostrar neste artigo por meio de numerosos exemplos e de pressupostos filosóficos relacionados à história da ciência. Mas, se sua historiografia não obscurece o papel que a metafísica importou à física, qual a procedência do engano de 
tantos intérpretes? Cremos que o principal motivo para que esse tipo de leitura viesse a ser feito repousa em uma extrapolação feita por alguns deles, a qual consiste em supor que Duhem transpõe integralmente suas reflexões normativas acerca da metodologia da física para o campo descritivo da historiografia da ciência, como se esta não fizesse senão suportar aquela. Como veremos, se a física deve ser uma disciplina autônoma com relação à metafísica, a história da ciência mostrará que nem sempre foi assim, e que a metafísica possuiu, em determinados casos, uma função central para o progresso da ciência. Em suma, acreditamos poder mostrar que a descrição dos fatos não é integralmente subordinada às normas metodológicas. Do ponto de vista histórico, a física nasceu e sustentou-se sobre aspirações metafísicas que resultaram na construção de sistemas cosmológicos determinados, e somente com a evolução secular pela qual ela passou a sua autonomia pôde ser amealhada. Assim sendo, a descrição adequada do nascimento da física teórica enquanto disciplina autônoma só será possível com a exposição das contribuições provenientes das mais variadas teorias cosmológicas, pois é do ventre das teorias cosmológicas que as teorias físicas vieram à luz.

\section{Antegedentes interpretativos}

Desde pelo menos Joseph Agassi uma linha interpretativa do pensamento de Duhem vem sendo defendida. Trata-se de ver em suas descrições históricas o resultado de uma concepção prévia, de cunho positivista, acerca do valor das teorias físicas. Dessa história, que não faria senão reafirmar sua própria filosofia da ciência, a metafísica estaria excluída, uma vez que esta não apresentaria um padrão de desenvolvimento contínuo (cf. Agassi, 1963, p. 31, 33) e, por assim dizer, "progressivo".

Do ponto de vista da historiografia, a interpretação de Duhem é defeituosa. Ela ignora o formidável impacto que doutrinas puramente metafísicas tiveram na história da ciência, a grande inspiração que a ciência extraiu de doutrinas puramente metafísicas como a indestrutibilidade da matéria, a alma da natureza ou o atomismo. (...) Ela ignora o impacto da ciência sobre a metafísica (cuja importância pode ser mostrada pela história do determinismo) (Agassi, 1957, p. 246, grifo meu). ${ }^{\mathbf{1}}$

\footnotetext{
1 Das três doutrinas metafísicas citadas por Agassi como tendo sido ignoradas por Duhem, digamos desde já que, a despeito do breve tratamento, a teoria da alma do mundo, estreitamente vinculada à teoria do grande ano, é analisada por ele no primeiro volume de $O$ sistema do mundo (Le système du monde) (p. 246- - 1 ), assim como a teoria do grande ano (p. $65^{-8} 5^{2}, 275^{-96}$ ). A teoria da indestrutibilidade da matéria, desde que ela possa ser traduzida na teoria
} 
A leitura da citação acima permite que apuremos qual seria, segundo Agassi, a amputação história cometida por Duhem. Não apenas ele teria menoscabado a influência da metafísica sobre a ciência como, inversamente, as contribuições históricas da ciência para a metafísica. Trocando em miúdos, a história duhemiana da ciência não patentearia qualquer intercâmbio com a história da metafísica. Física e metafísica seriam como que dois blocos separados e estanques, que evoluiriam de modo assaz divergente.

A fortuna das críticas de Agassi reservou-lhes novos aportes, da qual Lakatos é um dos herdeiros mais reconhecidos. Se o filósofo húngaro reconhece o apreço de Popper pela "metafísica influente", ele o separa de Duhem, incluído na "maré antimetafísica" da historiografia, que seria suplantada apenas por Burtt, Koyré e pelo próprio Popper (cf. Lakatos, 1979, p. 227, nota 351). "Firme positivista" (Lakatos, 1989, p. 145, nota 32 ), Duhem não aceitaria que a metafísica pudesse exercer alguma influência sobre a física no presente e não reconheceria a fecundidade dessa influência no passado. Interpretação um tanto parecida, embora mais bem fundamentada que as demais, pode ser encontrada na leitura de Pablo Mariconda. Para o comentador, ao estudar a ciência dos séculos xvi e xviı, Duhem estaria cometendo uma espécie de "anacronismo metodológico" (Mariconda, 1994, p. 151), uma vez que a leitura duhemiana daqueles séculos seria feita com a finalidade de confirmar a metodologia falibilista que viria a ser amplamente defendida apenas no futuro (no século xx, em particular). Ora bem, como Mariconda parte do pressuposto de que a teoria da ciência do filósofo francês é concebida nos moldes instrumentalistas, os elementos cosmológicos (metafísicos) recebem naturalmente uma atenção diminuta na exposição do debate astronômico do século xVII, encontrada especialmente em Salvar os fenômenos (cf. Mariconda, 1994, p. 157), toda a questão seria reduzida a uma disputa meramente astronômica. Munido desse padrão interpretativo, nosso autor seria levado em sua reconstrução histórica a condenar retrospectivamente a concepção metodológica realista de Galileu e de seus contemporâneos, deixando de notar que essa concepção era entendida, à época, como uma exigência que serviria de marca distintiva da superioridade de sua ciência diante da ciência do passado. Segundo Mariconda, "toda sua historiografia se ressente dessa tendência a procurar reconstruir a história da ciência de modo a torná-la compatível com as exigências de uma concepção instrumentalista do método científico", de modo que essa história torna-se "uma história de teorias - constructos matemáticos - constantemente desenvolvidas e melhoradas por pessoas que aderiram conscientemente ao

da eternidade da matéria primeira, ligada à teoria oposta, a teoria da criação da matéria primeira, é também discutida no Sistema durante a terceira e quarta partes da obra, embora não de modo sistemático e contínuo, já que ela é analisada isoladamente em cada autor estudado. Em algumas oportunidades dessas duas partes, a doutrina da alma do mundo será retomada. Sobre o atomismo, ver a seção 4 deste artigo. 
método de salvar os fenômenos". Daí que o francês seja "levado a ignorar totalmente o impacto que as doutrinas metafísicas tiveram sobre o desenvolvimento da física" (Mariconda, 1994, p. 152). Apoiado inicialmente nos textos que Duhem dedicou à contribuição mecânica de Galileu e à defesa galilaica do sistema copernicano, ${ }^{2}$ Mariconda prolonga as qualificações acima a toda a produção historiografia duhemiana, doravante subsumida em um mesmo padrão histórico de reconstrução.

\section{Pressupostos E Divisões iniciais}

Mesmo reconhecendo que as hipóteses não são na prática o resultado de generalizações indutivas a partir da experiência (cf. Reflexões, p. 17-9; Leite, 2007, p. 24-42, 55-70; 2012, p. 363-79) e que elas não devem ser deduzidas de sistemas cosmológicos (cf. FisMet), Duhem parece disposto a aceitar que durante a elaboração da teoria ambos os recursos possuem alguma influência. A observação, por exemplo, pode sugerir uma hipótese que a experiência, em seguida, encarregar-se-á de testar e/ou indicar alguma modificação (cf. Duhem, 1917, p. 152-3). Não há, afirma o filósofo, um método que, seguido com rigor, possa determinar invenções teóricas; a invenção não está sujeita a nenhuma regra fixa. Do ponto de vista da análise lógica, ${ }^{3}$ a mesma análise que mina o indutivismo genético e o apriorismo metafísico, inexiste qualquer conjunto de procedimentos que prescreva a elaboração ou escolha de alguma hipótese. Disso decorre que a lógica não pode ser a única referência do físico em suas escolhas, o qual deve recorrer a outros parâmetros, mais determinados, quando da construção de suas teorias. Precisar de quais fundos esses empréstimos podem ser tomados torna-se uma questão de grande relevância. Desejamos mostrar, a partir de agora, que, entre os fatores vislumbrados por Duhem como contributivos para a elaboração teórica, um amplo espaço é deixado para a intromissão das questões metafísicas. Podemos distinguir três níveis dessa influência metafísica, em grau crescente:

\footnotetext{
2. Os textos são, respectivamente, Estudos, 3, p. 562-83; 1984 [1908], p. 96-105. Em sua argumentação, Mariconda parece desconhecer outras três ocorrências em que Duhem dissertou sobre Galileu, que são: Duhem, 1904, p. 887901 (este, em especial, sobre a dinâmica galileana), Origens, 1, p. 236-62; 1996 [1911], p. 190-3.

3 No decorrer deste artigo, bem como em seu próprio resumo, utilizamos os termos "análise lógica", "crítica lógica" e, de modo simplificado, "lógica", como sinônimos para designar o procedimento de exame racional do objeto, do método, da estrutura e do valor de conhecimento das teorias físicas. O próprio Duhem utiliza em várias ocasiões essas expressões indistintamente (cf. Teoria, p. xv; 1908, p. 16). Nesse sentido, o convencionalismo duhemiano, bem como sua distinção entre a física e a metafísica, decorrem especificamente da análise lógica das teorias, muito embora este tipo de análise não perfaça toda a teoria da ciência de Duhem, à qual devemos acrescentar ainda os resultados advindos da pesquisa histórica e as aspirações espontâneas do senso comum, que podem inclusive contrariar os resultados da primeira, criando por vezes tensões incontornáveis no pensamento do autor.
} 
(a) o nível das convicções filosóficas íntimas do cientista, que dirigem as suas escolhas teóricas;

(b) o nível das descobertas científicas coletivas e historicamente importantes, calcadas em especulações cosmológicas e

(c) a existência bem mais ampla de uma tradição de pesquisa metafísica concreta, que se revelou fecunda no curso de dois milênios.

Passemos a tratar de cada um desses níveis, na ordem em que acabamos de dispô-los. ${ }^{4}$

Segundo Duhem, é preciso distinguir dois momentos na composição de uma teoria física. O primeiro é aquele que antecede a exposição da teoria, quando as ideias que virão a constituir o seu fundamento ainda se encontram, no espírito do físico, um pouco confusas e ligadas a julgamentos de outras naturezas. A seguir, um momento bem distinto e subsequente, quando a teoria já recebeu os devidos acabamentos que lhe conferiram precisão e acabamento superiores; é o momento em que ela aparece depurada daqueles julgamentos confusos. Mas são exatamente esses julgamentos, responsáveis por ditar muitas de suas opções teóricas, que o físico mais se recusa a expor; o que vem a público são os resultados de longos esforços de pensamento, e nunca o real processo mental de inspiração. A natureza desses imperiosos pensamentos obscuros é explicitada sem rodeios:

Enfim, esses pensamentos filosóficos que dirigem os esforços dos físicos na escolha e na elaboração de suas teorias ligam-se com frequência a outros pensamentos filosóficos, àqueles que dominam suas crenças morais, que organizam sua vida interior, e uma justa repugnância, um legítimo pudor, conduzem-no a subtrair aos olhos estranhos a morada íntima de sua alma.

É, pois, raro que um físico deixe-nos penetrar nesse santuário filosófico onde, em uma semiobscuridade, repousam as ideias-mães de suas teorias. E, entretanto, enquanto suas confidências não nos entreabrirem esse asilo secreto, nós não compreendemos real e plenamente suas doutrinas, pois, se nos é permitido contemplá-las [somente] sob sua forma acabada nós não podemos adivinhar de onde saiu o germe do qual elas se desenvolveram (Duhem, 1907, p. 208-9; grifos meus). 
O que na teoria física é uma hierarquia límpida de proposições meticulosamente ordenadas, no espírito do físico é mais parecido com uma rede entrelaçada de pensamentos heterogêneos e indistintos. Na verdade, como sabemos desde "A escola inglesa e as teorias físicas", a lógica deixa um amplo espaço para os aspectos que lhe são estranhos na escolha das hipóteses, a saber, o ambiente circundante, as tradições herdadas, a educação recebida etc., são decisivos no condicionamento que leva o físico a tomar suas decisões (cf. Duhem, 1989c [1893], p. 84; Leite, 2012, p. 71-92). O que Duhem faz desta vez é relevar os elementos filosóficos influenciáveis. A importância do contexto de descoberta aparece ainda de modo mais incisivo que outrora, a ponto de ele ser valorizado não apenas como essencial à compreensão do surgimento das teorias, mas, não obstante, como necessário para a compreensão real da teoria em si mesma. O conhecimento angariado pelo contexto lógico de justificação interna que legitima as conclusões de uma teoria é apenas parcial. Ele proporciona o entendimento do esquematismo matemático e de sua conexão com a experiência, embora não permita aquilatar o significado histórico nem a gênese daquele esquematismo; por outro lado, a descrição das características externas que serviram de andaime para a formulação das proposições teóricas vem a completar as exigências de compreensão. À narrativa do percurso evolutivo que levou à construção teórica, uma biografia profunda da alma do teórico é necessária. A história deve juntar-se à psicologia na determinação completa do entendimento de uma teoria. É por aí que se justifica a introdução da metafísica nas análises duhemianas das teorias físicas. 5

Duhem reconhece que a metafísica atua incessantemente nas escolhas do físico, mostrando-se, inclusive, como fértil recurso no desenvolvimento da física. Outrossim, o que explica a sua tendência irresistível a fazer metafísica, a desejar tão ardentemente que suas teorias capturem a verdade que ele sente existir? "Uma tendência irresistível leva-nos a pesquisar a natureza das coisas materiais que nos cercam e a razão de ser das leis que regem os fenômenos que observamos. Esta tendência move todo homem, desde o selvagem mais supersticioso até o filósofo mais curioso" (Reflexões, p. 25). O homem possui uma tendência natural, espontânea, a fazer metafísica, a tentar alcançar o conhecimento absoluto da natureza das coisas materiais. A teoria física, de nenhum modo construída com a intenção que os utilitaristas e pragmatistas atribuem a ela, resulta das incessantes inquietações do espírito humano em encontrar

5 É evidente que o autor do Tratado de energética (Traité d'énergétique), físico de formação, mantém a distinção entre os contextos de descoberta e de justificação, em especial quando escreve seus tratados de física. Mas não nos esqueçamos de que mesmo em uma obra como o Tratado (Duhem, 1911, 1, p. 5) ele assevera que os princípios de sua energética possuem uma justificação histórica (!), que eles são o fruto de uma longa evolução, o resultado secular de adaptações sucessivas à realidade. Logo, se a lógica atesta o valor convencional dos princípios da termodinâmica, a história indica ao físico qual o grau de confiança que neles se pode prudentemente depositar. Em uma palavra: a tradição é um recurso legítimo e recomendado no caso da escolha de hipóteses. 
a verdade última sobre o mundo físico, pois “não seria razoável trabalhar para o progresso da teoria física, se essa teoria não fosse o reflexo cada vez mais nítido e mais preciso, de uma metafísica; a crença em uma ordem transcendente à física é a única razão de ser da teoria física" (Duhem, 1908, p. 18). Na crença sempre presente de que a teoria física possa aproximar-se progressivamente da realidade subjacente, os físicos trabalham e fazem progredir o conhecimento: "Frequentemente a ilusão inflama a atividade humana mais que o claro conhecimento do objeto a perseguir" (FisMet, p. 59). Levados pela ilusão metafísica, pensadores como Descartes e Huygens "mostram que se pode dar às teorias físicas um prodigioso impulso", e que dessa ilusão se pode extrair "um poderoso e fecundo ardor pela pesquisa científica" (p. 59). Pois é exatamente essa crença de caráter realista e injustificada pela lógica que caracteriza a atitude dos físicos que se insurgem contra os ditames estreitos de uma análise puramente racional das teorias, a qual não vê nestas senão instrumentos de sistematização dos dados empíricos.

Toda a malha de influências que solicitam o físico e as escolhas concretas feitas por ele ao longo da história podem ser resumidas em uma passagem de um artigo de maturidade, quando Duhem já havia publicado os volumes dos Estudos sobre Leonardo da Vinci (Études sur Léonard de Vinci) e boa parte do Sistema do mundo já tinha sido escrita:

As hipóteses sobre as quais repousa uma teoria qualquer da mecânica ou da física matemática são os frutos cuja maturidade foi preparada por muito tempo; dados da observação comum, resultados da experiência científica auxiliada por instrumentos, teorias antigas hoje esquecidas ou rejeitadas, sistemas metafísicos e até mesmo crenças religiosas contribuíram para o seu advento; suas ações se cruzaram, suas influências se misturaram de uma maneira tão complexa que é preciso uma grande sutileza (finesse) de espírito, sustentada por um conhecimento aprofundado da história, para discernir as direções essenciais da via que conduziu a razão humana à clara percepção de um princípio da física (Duhem, 1915, p. 118-9; grifos meus).

As distinções entre a observação comum e aquela assistida por instrumentos, entre os sistemas metafísicos e as crenças religiosas e entre teorias esquecidas e falsas que contribuíram para o advento da física moderna evidenciam o caráter ponderado e reflexivo da passagem em destaque, na qual são retomadas várias das teses duhemianas. Dizemos que são retomadas, pois todas elas podem ser encontradas desde os seus primeiros artigos, inclusive o julgamento sobre a importância histórica da metafísica no progresso das teorias físicas. Que Duhem não tenha aprofundado o estudo das relações entabuladas entre física e metafísica desde o início de suas publicações é o resultado 
da natureza delas. Tratava-se naquela situação principalmente de usar a história para defender um projeto científico contra a invasão das teorias reducionistas de caráter metafísico. Nesses textos, as teorias metafísicas aparecem para ser combatidas; contudo, o caráter combativo da história incipiente não se converte em negação da presença daquelas. Lembremos que antes da descoberta da ciência medieval, afora Aristóteles, a história da ciência duhemiana cobria exclusivamente os três últimos séculos e, mesmo restrita, ela levava em consideração a importância na física da metafísica, a qual era situada nas explicações fornecidas pelas diferentes escolas cosmológicas, a saber, o peripatetismo, o cartesianismo, o atomismo, o newtonianismo e o renascimento, no século xix, de um novo cartesianismo (cf. Duhem, 1896b). Havia ali, portanto, um grau de reconhecimento da relevância da metafísica que se expandirá, com o recuo histórico provocado pela guinada historiográfica, para épocas anteriores ao estabelecimento da ciência moderna, nas quais a prevalência da metafísica será prontamente reconhecida. ${ }^{6}$

A primeira parte de "Uma nova teoria do mundo inorgânico" (Duhem, 1893), por exemplo, é inteiramente dedicada à exposição do sistema cosmológico do padre Leray; a segunda e última parte do artigo, de igual extensão, é escrita para criticar as teorias mecânicas que procuram deduzir consequências físicas de hipóteses metafísicas, e, ao mesmo tempo, é acompanhada de uma descrição histórica das relações entre a física e as ideias cosmológicas. No ensaio, o autor reconhece que os esforços mecanicistas de Descartes em sua tentativa filosófica de compor a máquina do mundo não foram em vão, e que seria uma "injustiça” ignorar os resultados dos mesmos (cf. 1893, p. 116). A física geral foi influenciada pelo reducionismo cartesiano: não se poderia mais incolumemente manter a superficialidade escolástica que consistia em designar para cada efeito natural uma propriedade específica responsável pela sua aparição. Uma "consequência útil e prática" da filosofia cartesiana é evitar a explicação por acréscimo de novas virtudes, sem a tentativa anterior de reduzir os novos efeitos a causas mais gerais e profundas. Essa recuperação do valor explicativo era nada menos que uma das condições do sucesso da física teórica. É ela que influenciará, para bem ou para mal, Pascal, Huygens, Newton e, principalmente, Leibniz (cf. Duhem, 1893, p. 116-7, 117-9, 119-22, 123-6).

6 Por "guinada historiográfica" entendemos o momento cronológico que caracteriza e sucede a descoberta acidental da estática medieval, ocorrida durante a composição de As origens da estática (Les origines de la statique) no segundo semestre de 1903, e que reorientou profundamente o caráter da produção duhemiana e a natureza de muitas de suas teses historiográficas. À descoberta da estática medieval, outras se seguirão nos próximos anos, em especial, a da dinâmica dos mestres parisienses do século xiv. Graças a elas, obras como os Estudos e o Sistema vieram ao mundo. Para maiores detalhes sobre a guinada historiográfica e sobre as duas descobertas mencionadas, ver, respectivamente: Leite, 2012, p. 31-51, 189-222. 
Inversamente, Newton, que se deixou animar pela cosmologia cartesiana, tornou-se, ele mesmo, fonte da qual uma nova cosmologia seria extraída. Se Descartes foi mais importante por sua exigência, metafísica, de inteligibilidade da natureza, o inglês foi mais importante enquanto físico e instaurador de uma nova maneira de tratar a física; suas teorias marcam o ponto de partida de uma das mais fecundas evoluções teóricas da humanidade (Duhem, 1893, p. 119; 1896b, p. 484; 1903b, p. 25-31). Foi o sucesso "prodigioso" da física newtoniana durante mais de um século que fez com que a teoria das ações à distância fosse considerada uma verdadeira explicação metafísica: "Os progressos da física criada por Newton não tardaram a fazer triunfar essa metafísica que, muito injustamente, atribuem a ele" (1893, p. 123). A "espantosa fecundidade" (p. 126) da teoria newtoniana fez que ela se tornasse um modelo explicativo a ser aplicado em diversas áreas da física como a eletricidade, a capilaridade, a elasticidade e o calor. Mais do que isso, ela gerou um verdadeiro programa de pesquisa metafísica, pois, audaciosamente, Laplace escreverá sobre “atrações moleculares”, e Poisson intentará reduzir todos os fenômenos a "ações moleculares" conforme a verdadeira natureza das coisas (p. 126-7).

Mas não é só. Também a termodinâmica, ciência recente à época em que nosso filósofo escrevia, já dera provas de suas implicações filosóficas. Com efeito, desde o seu primeiro artigo epistemológico, Duhem expunha a influência mútua "muito íntima, muito potente" entre a metafísica e a física de várias épocas (Reflexões, p. 29), ${ }^{7}$ e são os escritos de Herbert Spencer que ele menciona como exemplo de uma filosofia que foi impregnada pelas ideias científicas extraídas da termodinâmica. Todavia, o que atrai sobremodo nossa atenção são os critérios utilizados no julgamento da fecundidade da termodinâmica. A fecundidade de uma teoria tem de ser julgada, consoante o filósofo, a partir de um tríplice ponto de vista: (i) a sistematização teórica alcançada, que poderá vir a sugerir novas experiências, (ii) a aplicação industrial na invenção ou melhoria de técnicas disponíveis e, surpreendentemente; (iii) o aporte metafísico. Neste caso, os trabalhos de Carnot que se propunham a melhorar o rendimento dos motores térmicos são proverbiais. Dentre as consequências de seus estudos sobre o poder motriz do fogo encontramos de inusitado uma influência que acabou por ultrapassar a engenharia. Seus resultados foram além das aplicações práticas e serviram como base de especulações metafísicas. Assim, "de um pequeno escrito de física industrial saiu uma nova filosofia da natureza" (Duhem, 1899, p. 394). Os escritos de Carnot relativos ao segundo princípio da termodinâmica, cuja finalidade era totalmente alheia à filosofia, foram o motivo de cogitações cosmológicas. Por seu turno, algo oposto sucedeu 
com o primeiro princípio da termodinâmica, pois, diz-nos Duhem, é impossível separar o nascimento do princípio de conservação de energia da afirmação de que o calor é uma forma de movimento local, hipótese filosófica por excelência (cf. Duhem, 1898, p. 55). "Nascida da hipótese de que o calor é um movimento, a termodinâmica moderna vai liberar-se dessa suposição e, mesmo, voltar-se contra ela, determinando a sua rejeição" (1895b, p. 415; cf. 1895c). A termodinâmica é um caso modelar, pois, se ela dá origem a ilações metafísicas, pode também ser vista como se tendo originado destas, e até como uma reação a elas. As implicações históricas entre a física e a metafísica estabelecem-se em um processo cíclico e complexo. Ao evoluir, a teoria física reduz o escopo das especulações filosóficas, mas não as elimina por completo, não impossibilita a investigação das causas. Apenas constrange e condiciona a imaginação do cosmólogo. ${ }^{\mathbf{8}}$

Tais considerações conduzem-nos a introduzir e apregoar que uma divisão de suma importância seja feita entre os preceitos metodológicos, que visam a eliminar a invasão metafísica prejudicial à autonomia da física, e o relato histórico, que descreve as influências metafísicas (profícuas ou não) no desenvolvimento histórico da ciência. Essa distinção mostra sua pertinência quando procuramos compreender os pressupostos e o tom das críticas desferidas à historiografia de Ernst Mach na resenha duhemiana escrita por ocasião da tradução francesa de sua conhecida obra de mecânica. Tal qual Mach, Duhem nega à metafísica o poder de impor ao físico determinados princípios sobre a constituição da matéria, mas, ao contrário do austríaco, várias vezes ele reconhece que durante a história as crenças metafísicas ilusórias contribuíram para o progresso do conhecimento. O exemplo duhemiano usado em sua crítica tem, mais uma vez, em Newton seu ponto de apoio. Seria impossível entender as críticas feitas à teoria newtoniana pelos atomistas e cartesianos sem remontar às discussões metafísicas sobre a forma, a matéria, a quantidade e a qualidade que agitaram as discussões medievais. Até mesmo a ideia da atração universal de Newton teria brotado da terra fértil das concepções astrológicas:

Essa ação e reação incessantes das ciências filosóficas e teológicas sobre a mecânica e a física deve estar constantemente presente ao espírito daquele que pretende ressuscitar as maneiras de pensar dos criadores da ciência (Duhem, 1903a, p. 270).

8 Essa lição será reafirmada com clareza no artigo "Física do crente" (Duhem, 1981 [1905], p. 464-5). 0 metafísico desejoso de construir a sua cosmologia tem por obrigação seguir os progressos da física para não investir contra os conhecimentos admitidos em sua época. Uma vez que a cosmologia é a ciência que busca conhecer as causas dos fenômenos, é imperativo que ela respeite as aquisições da ciência responsável por estudá-los. Quanto maior for o desenvolvimento da ciência física, menor será o espaço reservado à livre imaginação do cosmólogo, pois a seleção que acomete as teorias físicas aflige igualmente as especulações metafísicas, dado que ambas devem adequar-se aos dados empíricos. 
Se não se trata de julgar, e sim de compreender o que os pensadores de antanho disseram, é preciso ampliar o estudo sobre a gênese das teorias e ver nestas a convergência de diversas sortes de ideias. A história de Mach, forjada nos moldes do mais puro espírito antimetafísico, não seria realmente escrita para historiadores, não seria tratada como um fim, mas como um meio, um expediente para defender sua própria concepção científica, justificando as ideias por ele defendidas; ela "não tem por objeto fazer reviver aos nossos olhos" as ideias do passado, detalhando a longa e complexa evolução das teorias (cf. Duhem, 1903a, p. 268). Essa abreviação resulta, é Duhem quem o declara, em implacável amputação na qual os excessos eliminados são exatamente aqueles que menos interessariam ao austríaco, a saber, as relações permutadas entre a física e a metafísica. A reconstrução histórica machiana abeira-se da história whiggista, pois os erros e as grandes disputas são deixados de lado. Mas é imprescindível notar que a estrita observância do método positivo seria tão somente uma realidade do presente: no passado, a física ligava-se intimamente com a metafísica, a teologia e, mesmo, com as ciências ocultas (cf. Duhem, 1903a, p. 270). 9 Como, doravante, caracterizar a historiografia duhemiana como anacrônica se o próprio espírito que anima a crítica de nosso autor a Mach ampara-se em pressupostos antianacrônicos? É nesse sentido que as críticas a Mach convertem-se em elogios a Paul Tannery. Em artigo laudatório dedicado a homenagear o amigo há pouco falecido, Tannery é lembrado por atender às expectativas condizentes com a sã metodologia da pesquisa histórica.

As ciências físicas e biológicas exerceram uma profunda influência sobre a gênese de muitos sistemas metafísicos e, certamente, ninguém o sabia melhor que o autor de Em favor da ciência helênica. Inversamente, as doutrinas filosóficas frequentemente reagiram sobre os métodos científicos, e Paul Tannery não o ignorava (Duhem, 1905, p. 227). ${ }^{10}$

A posição de Tannery parece justificar-se aos olhos de Duhem, pois o compatriota já havia estabelecido uma verdade histórica que deveria tornar-se definitiva, ou seja, os pensadores gregos anteriores a Platão eram, antes de tudo, fisiólogos, isto é, eles estavam preocupados principalmente com questões cosmológicas, relegando a

9 Quer-nos parecer que Duhem comete alguns exageros em sua crítica a Mach. No capítulo sobre os "Pontos de vista teológico, animista e místico na mecânica" (Mach, 1960 [1893], p. 446-65), o autor reconhece que grandes cientistas foram também religiosos e que entre a Igreja e a ciência existiram relações conflituosas amplamente conhecidas. Talvez o objeto preciso das críticas duhemianas seja sobretudo a generalidade e brevidade excessivas no tratamento dado por Mach a essas relações.

10 O título completo da obra de Tannery, publicada pela primeira vez em 1887, é: Pour l'histoire de la science hellène: De Thalès à Empédocle. Como observa Brenner (2004, p. 45), Tannery é, juntamente com Giovanni Schiaparelli e Thomas-Henri Martin, uma das fontes usadas no Sistema do mundo no que concerne à astronomia. 
metafísica geral a um plano de menor importância (cf. Duhem, 1905, p. 220). Desde a Grécia antiga as preocupações cosmológicas ligavam-se estreitamente à curiosidade científica. Pois bem, se Tannery separa "essencialmente" a física da metafísica, ele não deixa de notar as relações históricas estabelecidas entre a ciência e os sistemas filosóficos (p. 227). As sabedorias antiga e medieval estavam frequentemente ligadas a visões de mundo integrantes de alguma filosofia e, em decorrência, é tarefa do historiador da "ciência" consagrar a devida atenção ao estudo do pensamento cosmológico. Um dos casos destacados por Duhem em sua análise do método histórico praticado pelo colega é retirado da astrologia judiciária. O lógico, diz ele, deverá estudar com cuidado a obra de Tannery, em especial suas reflexões sobre o impacto que a astrologia judiciária teve sobre a astronomia. Teria sido a astrologia a responsável pela conservação do interesse astronômico em uma época, a Idade Média, em que o interesse científico diminuiu. Enquanto a astronomia era vista como um meio para as predições astrológicas, ela conservou a matemática pura, evitando que esta degenerasse em meros cálculos mercantis (cf. Duhem, 1905, p. 224).

Desde A teoria física (La théorie physique) Duhem estava disposto a aceitar as influências positivas que a astrologia havia legado à astronomia: "A invenção não está sujeita a nenhuma regra fixa. Não há doutrina tão estúpida que não tenha podido, algum dia, suscitar uma ideia nova e feliz. A astrologia judiciária teve sua parte no desenvolvimento dos princípios da mecânica celeste" (Teoria, p. 144). Como inexiste um método rigoroso de invenção, mesmo uma concepção falsa do método científico, insiste o professor de Bordeaux, pode trazer contribuições positivas para a ciência. Assim como ele jamais nega que a ciência obteve ganhos com as teorias mecanicistas, esta teve na astrologia uma preciosa aliada: "veremos, aliás, que o papel dos médicos e dos astrólogos não foi de mínima importância no desenvolvimento da doutrina da atração universal" (Teoria, p. 34,8-9). Os ensinamentos astrológicos de Ptolomeu sobre os efeitos da Lua sobre a Terra eram amplos e a influência lunar era reconhecida não somente nas marés (cf. Sistema, 2, p. 267-39o), mas, igualmente, nos seres vivos, resultando na alteração mesma de sua saúde: "A astrologia, desde então, torna-se a indispensável auxiliar da medicina” (Sistema, 2, p. 365). ${ }^{\mathbf{1 1}}$ As ideias de Ptolomeu, Albumasar, Júlio César Scaliger, Gilbert, "são conservadas pelos médicos e astrólogos da Idade Média e da Renascença” (Teoria, p. 358-9) a ponto de atingirem Kepler e contemporâneos seus.

11 Acreditava-se, na Idade Média, que o assunto da astrologia estava estreitamente vinculado ao da medicina, de modo que os astros influenciariam a saúde do corpo e, em decorrência, o tratamento das doenças. Julgava-se que a astrologia poderia inclusive indicar os dias críticos em que as crises iriam se manifestar ou diminuir. Não era comum separar, na Marselha do século xII, o estudo da astrologia e da astronomia: "se se seguia o curso dos astros, era sobretudo com o objetivo de prever o futuro; era-se, ao mesmo tempo, astrônomo e astrólogo, e era-se astrônomo a fim de poder ser astrólogo" (Sistema, 3, p. 205). 
Em Teoria física, Duhem não vai muito além disso. Pelo contrário, no Sistema do mundo, ele busca na cosmologia de Aristóteles as raízes da astrologia e, na teologia cristã, as causas do nascimento da ciência moderna. Mas como?

\section{A revoluçÃo teológiga E O NASGimento DA GiÊNGia Moderna}

Por falta de espaço ou de relevância argumentativa, não iremos, neste artigo, mencionar ou detalhar todos os elementos que Duhem elege na cosmologia peripatética como fundamentais para a justificação de vários dos dogmas da astrologia. Não obstante, é preciso recordar que Aristóteles distinguia quatro tipos de movimento presentes no mundo sublunar corruptível, quais sejam, o movimento local ou de translação, no qual um corpo desloca-se de uma parte a outra, o movimento qualitativo, pelo qual o corpo sofre uma alteração (mudança de intensidade de uma mesma qualidade ou de uma qualidade a outra), o movimento quantitativo, de aumento ou diminuição, os quais Duhem aproxima intencionalmente dos conceitos de dilatação e contração (cf. Sistema, 1, p. 161), e o quarto e último movimento, mais profundo, que corresponde à chegada ou desaparecimento de um ser e, por isso, é chamado de movimento de geração ou corrupção, também conhecido como movimento substancial. Por sua vez, de todos os movimentos, o movimento local é aquele que recebe o maior privilégio, no sentido de que os outros três dependem dele para a sua realização. Nenhuma geração, corrupção, aumento, diminuição ou alteração seriam possíveis sem que o movimento local aproximasse e distanciasse os corpos que determinam esses movimentos (Sistema, 1 , p. 162). Todos os demais movimentos, excetuados os movimentos locais, são definidos como a atualização de uma potência por uma forma, ou seja, como um processo finito, pois que se uma transformação teve um início ela também deverá ter um fim, o qual se dá quando a forma é finalmente adquirida. Algo bastante distinto ocorre com o movimento de translação circular, pois, apesar de simples como os movimentos retilíneos, ele não possui, como estes, qualquer contrário ou limite, e pode, portanto, ser eterno, sem termo. E, por isso mesmo, de todos os movimentos simples, ele é o único que pode ser encontrado nos céus, como característico dos corpos supralunares, dada a ausência, na região celeste, de geração, corrupção, alteração, “dilatação" ou "contração". Poder-se-ia, conseguintemente, estabelecer uma relação direta de dependência: os movimentos locais celestes, simples e eternos, seriam como que a condição dos demais tipos de movimentos que se processam apenas no mundo sublunar, pois sem aqueles estes não seriam o caso. Daí uma consequência de suma importância pode ser derivada: 
Este mundo está ligado de algum modo, e de uma maneira necessária, aos movimentos locais do mundo superior, de sorte que toda a potência que reside em nosso mundo é governada por esses movimentos (Aristóteles apud Duhem, Sistema, 1, p. 164). ${ }^{12}$

No mundo terrestre, onde as transformações são constantes, todos os movimentos de geração e corrupção são dependentes do movimento local dos seres imperecíveis e imutáveis (Sistema, 2, p. 317): "Esse princípio e esse texto serão reivindicados por todos aqueles que, na Antiguidade e na Idade Média, pretenderão justificar a ciência astrológica" (Sistema, 1, p. 164). A periodicidade dos movimentos circulares dos corpos celestes acarreta a periodicidade dos movimentos de geração e corrupção nos corpos sublunares, como o atestam as estações anuais, as chuvas, o ciclo de vida dos animais e vegetais etc. (cf. Sistema, 1, p. 166). As circulações celestes governam imperiosamente os movimentos sublunares, em uma espécie de "determinismo rigoroso", onde cada mudança terrestre é o resultado do movimento de um astro (cf. Sistema, 2, p. 39o).

Se as crenças astrológicas manterão ainda alguma predominância entre os espíritos, elas o farão a contragosto dos padres da Igreja, interessados em manter intacto o livre-arbítrio humano. É bem verdade que estes não possuíam uma ciência minuciosa e, decerto, não se preocupavam tanto com as ciências naturais (cf. Sistema, 2, p. 395$7,407)$, no entanto, sua pretensão apologética levou-os forçosamente a ocuparem-se com a física e com a astronomia (Sistema, 2, p. 393). Entre os ensinamentos dos livros sagrados e a ciência pagã, o conflito instaura-se e a descrição que a ciência oferece dos céus parece ser inconciliável com a narrativa do Gênesis. O fatalismo astrológico, que "submete todos os atos humanos ao império inflexível das revoluções astrais" (Sistema, 2, p. 4,04), teria introduzido um determinismo estrito a ponto de negar o livrearbítrio dos homens e, em decorrência, a responsabilidade por seus atos. ${ }^{\mathbf{3}}$ Com isso, o cristianismo, condenando aqueles que pretendem prever o futuro por meio das relações vigorantes entre os astros, lança uma guerra obstinada que terá o seu ápice no século XIII.

Todas as cosmologias helênicas são, em última análise, teologias; no coração de cada uma delas nós encontraremos dogmas religiosos (...). Esses dogmas, aliás,

12 Duhem marca a influência histórica e a força exercida por essa passagem dos Meteorológicos de Aristóteles também no volume seguinte do Sistema do mundo, quando, após retomá-la, acrescenta: "Em virtude desse dogma os filósofos antigos reduziram a física inteira a uma imensa astrologia” (Sistema, 2, p. 368).

13 Algumas passagens do primeiro volume do Sistema do mundo já antecipavam a tese do segundo volume na qual Duhem defende que teria sido o cristianismo a principal causa da derrocada do determinismo astrológico (Sistema, 1, p. 261, p. 296). 
tomados no que eles têm de essencial, são os mesmos em todas as filosofias gregas; são aqueles que as escolas pitagóricas da grande Grécia ensinavam: os corpos celestes são divinos, e são os únicos deuses verdadeiros; eternos e incorruptíveis, eles não conhecem outra mudança exceto o movimento perfeito, circular e uniforme; por meio desse movimento, eles regulam, segundo o mais rigoroso determinismo, a marcha de todas as mudanças das quais o mundo sublunar é o teatro.

Ora, a ciência moderna nascerá, pode-se dizer, no dia em que se ousar proclamar esta verdade: a mesma mecânica, as mesmas leis regem os movimentos celestes e os movimentos sublunares, as circulações do Sol, o fluxo e o refluxo do mar, a queda dos graves. Para que fosse possível conceber tal pensamento, era preciso que os astros fossem destronados da categoria divina na qual os tinha colocado a Antiguidade, era preciso que uma revolução teológica fosse produzida. (...) Essa revolução será a obra da teologia cristã (Sistema, 2, p. 453).

A ciência moderna nascerá do choque de duas teologias, quando a teologia cristã decidir enfrentar a teologia pagã. Esta afirmação, uma das mais caras teses historiográficas a Duhem, será desenvolvida com pormenores no corpo do Sistema do mundo, mas está claro que, desde o segundo volume da grandiosa obra, ele já tem formulado o critério que servirá para estipular o nascimento da ciência moderna, que é o de unificação das mecânicas, até então cindidas entre as mecânicas terrestre e celeste, cuja semente fora plantada na Universidade de Paris. A revolução que tornou possível a ciência moderna é tributária de uma disputa ocorrida no terreno contíguo da teologia. Foi a teologia cristã que, inicialmente em 1277, com Estevão Tempier (e com João Buridan, Nicolau Oresme e Alberto de Saxe durante os cem anos seguintes), ousou condenar, em uma síntese de 219 teses, o que as doutrinas pagãs herdadas da Antiguidade e os escritos peripatéticos recém-redescobertos tinham de contrário à fé. Somente com a condenação o espírito humano viu-se livre para ensaiar novas possibilidades cosmológicas (para maiores detalhes, cf. Leite, 2012, p. 3०4-25, 379-88). A tese segundo a qual a dinâmica moderna nasceu em meio e graças a discussões teológicas que geraram uma nova visão ou sistema do mundo é parceira de outra tese, que pode ser formulada contrafatualmente: não fosse a teologia, a ciência moderna simplesmente não teria nascido tão cedo, nas circunstâncias em que nasceu. Apenas a disputa teológica entre dogmas opostos pôde romper com as amarras gregas do passado, em particular, do peripatetismo. Rejeitada em seus fundamentos, a cosmologia de Aristóteles pôde então ser contestada de vários ângulos, ocasionando uma espécie de reorientação do pensamento físico. Se Duhem separa a discussão astronômica da discussão teológi- 
ca no Sistema do mundo é por uma preocupação meramente didática, como anunciado no terceiro tomo da obra. ${ }^{14}$

Vê-se que não foi uma revolução antimetafísica que criou a ciência moderna, como professavam à época os historiadores positivistas, porque esta nasceu no seio de uma verdadeira revolução teológico-metafísica. A metafísica (ou a teologia cristã) não impediu, mas propiciou o nascimento da ciência moderna. Os progressos que lançaram os fundamentos da nova ciência deram-se, como insiste Bulliot, neotomista e amigo de nosso autor, em plena "atmosfera metafísica", pois, continua ele, Buridan, Oresme e Saxe (os dois últimos, discípulos do primeiro) eram, antes de tudo, pensadores cristãos ciosos de sua crença; muito das bases da dinâmica, da astronomia e da geologia modernas é devido ao triunvirato de mestres da Universidade de Paris (Bulliot, 1914, p. 6).

Como pudemos perceber, Duhem reconhece as influências metafísicas sobre o cientista e sobre o desenvolvimento das teorias físicas, as quais retroagem a seguir sobre a metafísica (a física moderna termina por sepultar de uma só vez tanto a dinâmica peripatética quanto a sua teologia). ${ }^{\mathbf{1 5}}$ Nosso próximo exemplo introduz um novo nível (o nível "c" a que nos referimos no início da seção 2) das relações assumidas entre a física e a metafísica, que agora prolongam-se por séculos, podendo ser descritas como constituindo uma tradição metafísica milenar de pesquisa, responsável pela fecundidade das teorias que viriam a formar a estática moderna.

A primeira grande publicação historiográfica de Duhem, As origens da estática, não contém nenhuma exposição aprofundada sobre quaisquer doutrinas cosmológicas. A estática estudada nos dois volumes mistura-se frequentemente com questões referentes à dinâmica, área afim, mas nada que exceda uma história de teorias “cientí-

14. "Assim, a doutrina católica, de uma parte, e, de outra, a ciência experimental, representada pelo sistema de Ptolomeu, iriam se lançar à batalha; o adversário de ambas era o mesmo: o partido de Aristóteles e daqueles que o seguiam. (...) Em função da clareza da exposição, ser-nos-á preciso conduzir separadamente as narrativas dessas duas batalhas, cujas peripécias diversas, durante um século, encontraram-se misturadas de um modo tão íntimo" (Sistema, 3, p. 24,3).

$15 \mathrm{O}$ principal exemplo dessa reação não poderá ser examinado por nós nesta oportunidade, embora mereça muito bem ser indicado nesta nota. Trata-se da teoria do impetus de Buridan, que, motivado pelo decreto do bispo Tempier, formula uma explicação alternativa à de Aristóteles para a permanência dos movimentos dos corpos celestes. É nessa teoria que Duhem verá os germes positivos de boa parte da ciência moderna. Ao prolongar a sua teoria do impetus aos movimentos supralunares, Buridan livra os teóricos e teólogos da hipótese peripatética da existência de inteligências divinas responsáveis por moverem continuamente os orbes celestes, e dá os primeiros passos na unificação das dinâmicas celeste e terrestre. Não seria mais preciso admitir que cada orbe fosse movido por um deus particular, mas tão-somente que o Deus católico, ao criar o mundo, tivesse imprimido em cada orbe um impetus inicial que se conservaria eternamente na ausência de impedimentos externos. Agora, é a vez de a dinâmica celeste nascente agir sobre a teologia: "Não é somente a dinâmica do estagirita que sucumbe; é também a teologia desse filósofo" (Sistema, 8, p. 339). O politeísmo astral do filósofo grego recebe um golpe do qual ele não se recuperará (cf. Leite, 2012, p. $325-43)$. 
ficas". Em princípio, As origens parece relegar a um plano inferior as disputas metafísicas agentes durante todo esse período, mas, se atentarmos para algumas passagens, entenderemos melhor por que Martin, sem se preocupar de fato com a questão que nos toca, viu na descrição histórica ali fornecida uma ameaça à metodologia de nosso autor (Martin, 1976, p. 126).

Nessa obra, partindo de Aristóteles e Arquimedes, Duhem percorre mais de dois mil anos de uma evolução que culminou com a enunciação correta do princípio das velocidades virtuais, realizada por Jean Bernoulli. Logo no capítulo inicial do primeiro volume o autor distingue duas abordagens históricas recebidas pela ciência do equilíbrio. A primeira, cujo fundador seria um discípulo de Aristóteles, autor dos Problemas mecânicos (Mechanica Prolemata), faria da estática uma ciência subordinada à dinâmica: os princípios da primeira seriam retirados da segunda. $\mathrm{O}$ custo de semelhante método é o aumento da complexidade e da insegurança envolvidas na compreensão dos fenômenos do equilíbrio, já que os movimentos necessários à explicação destes são submetidos a princípios que parecem ocultos sob as aparências, ou melhor, que não são puras descrições dos fenômenos. Por outro lado, a segunda abordagem, fundada por Arquimedes, é caracterizada pelo rigor analítico e pela elegância dedutiva de suas conclusões, extraídas de princípios seguros cuja evidência nada deixava a desejar. O geômetra de Siracusa, então, inverte o procedimento de viés aristotélico e erige a estática de forma autônoma, independente das considerações sobre o movimento e sua natureza: "ele assegurou à sua doutrina uma perfeita clareza e um extremo rigor; mas, é preciso reconhecer, esta clareza e este rigor foram adquiridos a expensas da generalidade e da fecundidade" (Origens, 1, p. 11). Se o método algébrico de Arquimedes garante demonstrações precisas e certas, ele não funciona como um procedimento ou facilitador de invenções (p. 12). Ao contrário, o método aristotélico, muito mais ousado, devido às suas raízes cosmológicas, será aquele do qual sairão os maiores progressos em estática. A fecundidade encontrada em tal procedimento metodológico é ser explicada pelo fato de que, além de um método de demonstração, ele poderia ter servido como um método de invenção (Origens, 2, p. 280). A abordagem metodológica preconizada nos Problemas mecânicos será a principal responsável pela tradição da qual sairá o princípio das velocidades virtuais (Origens, 1, p. 8). O espírito intuitivo e filosófico do autor dos Problemas garante-lhe a penetração exigida para tratar das questões as mais obscuras, ao passo que ao espírito dedutivo e geométrico de Arquimedes restará o papel secundário que consiste em fazer o exame, a triagem e a justificação dos resultados obtidos pela intuição (p. 209), ou, se se quiser, enquanto o espírito filosófico promove o progresso, o espírito geométrico como que o remata (p. 263).

A breve narrativa do parágrafo anterior mostra que o método responsável pelo progresso da estática foi aquele que, baseado em considerações dinâmicas, entendeu o 
equilíbrio como um caso particular do movimento. Pois bem, a próxima coisa a ser observada é que estamos falando da dinâmica peripatética, a qual estuda os movimentos dos corpos inanimados. Mas a dinâmica do estagirita, Duhem sabia-o com nitidez, é um ramo da metafísica e, mais precisamente, faz parte do principal sistema cosmológico da Antiguidade. Se é assim, torna-se forçoso admitir que os progressos na estática, derivados principalmente da tradição dos Problemas mecânicos, deveram-se a um tipo de especulação fundamentalmente cosmológica. Isso significa reconhecer que o modelo arquimediano, citado em "Física e metafísica" como "o modelo das teorias tal como as entendemos" e responsável pela "primeira teoria da física matemática" (FisMet, p. $5^{3}$ ), não teria sido tão fecundo como se podia esperar. Pior: quase toda a fecundidade seria transferida ao método oposto, dependente de reflexões cosmológicas. Natural, portanto, o espanto de Martin diante da constatação tão positiva que nosso autor faz da tradição aristotélica em As origens, afinal, este não repudiara, em seus textos iniciais, a ingerência da metafísica nas questões da física? Reconhecer o sucesso do método oposto não seria o mesmo que condenar a sua própria metodologia, de feição instrumentalista? Àquela altura (Martin, 1976), o comentador não estava preparado para aceitar, como estamos, que, apesar de distinguir nitidamente física e metafísica do ponto de vista da lógica, de uma perspectiva histórica Duhem está disposto a reconhecer influências metafísicas favoráveis ao progresso da física. ${ }^{\mathbf{1 6}}$

É possível encontrar inúmeros outros exemplos isolados do entrelaçamento profícuo entre a física e a metafísica espalhados ao longo da gigantesca produção duhemiana, como o proveito que a física moderna teria tirado das discussões teológicas sobre a intensão e remissão das formas (intensione et remissione formarum), que representariam o início das tentativas de atribuir ou vincular ao acréscimo de uma qualidade, no caso, a caridade, o aumento de uma quantidade (Estudos, 3, p. 316); ou a longa digressão, nos Estudos sobre Leonardo da Vinci, sobre a metafísica de Nicolau de Cusa e sua ascendência sobre Da Vinci (Estudos, 2, p. 99-279), a qual será parcialmente retomada no Sistema do mundo (Sistema, 10, p. 247-347). Mas talvez a maior prova do grau de atenção que o historiador francês deu ao estudo da metafísica possa ser encontrada na terceira e quarta partes do Sistema do mundo, que têm, respectivamente, por títulos, "O aumento do aristotelismo" e "o refluxo do aristotelismo", e abrangem um espaço que se estende da segunda metade do quarto volume até o fim do sexto volume. As questões discutidas são, como o próprio Duhem anuncia no início da terceira parte (Sistema, 4,

16 É importante observar que Martin alterou o seu ponto de vista após 1976, passando a constatar, embora sem esmiuçar, o papel que a metafísica exerceu historicamente, para Duhem, sobre a física (cf. Martin, 1991). O mesmo pode ser dito de Roberto Maiocchi: a despeito da falta de análise acurada das obras duhemianas de cunho eminentemente historiográfico, o intérprete italiano é enfático ao insistir na atenção do francês para com as relações entremeadas entre a física e a metafísica (cf. Maiocchi, 1985, p. 273- ${ }^{3}$ ). 
p. 320); as relações entre a matéria e a forma e, em especial, a eternidade da matéria primeira; a natureza da matéria celeste; a teoria da alma humana; o princípio de individuação; as relações entre a essência e a existência - temas essencialmente metafísicos. Clagett já notara em resenha que o sexto volume do Sistema do mundo é sobretudo "de grande interesse ao estudante de filosofia medieval" (Clagett, 1958, p. 360). Sobre o quinto volume da obra, Martin, comentador abalizado de Duhem, referiu-se da seguinte maneira: "É difícil enxergar o que a preocupação de Duhem com a física tem que ver com os capítulos daquele volume sobre Alberto Magno, Tomás de Aquino e Sigério de Brabante, que têm cerca de cem páginas cada" (Martin, 1991, p. 10).

Retomemos as críticas feitas a Duhem por Mariconda, expostas na primeira seção deste artigo, com o fito de evidenciar o seu acerto e a restrição que devemos impor a elas, pois cremos que elas preservam alguma validade. Insistimos que aquelas críticas só podem ser sustentadas sob a condição de serem circunscritas principalmente a Salvar os fenômenos, obra que, de fato, elimina em grande medida a complexidade das relações históricas entre a física e a metafísica. O resultado, ali, é a redução do contexto histórico a uma diversidade de opiniões sobre o valor das teorias astronômicas entendidas como construções matemáticas. Mas este ensaio, por demais simplificador, não é uma obra eminentemente historiográfica, autônoma, pois nele a história aparece como que destinada a provar uma ideia filosófica prévia sobre o valor de conhecimento das teorias físicas. Quando Salvar os fenômenos era escrito, outra obra já estava em curso, sendo publicada sob a forma de artigos na Revue de Philosophie entre setembro de 1907 e maio de 1909. Trata-se de 0 movimento absoluto e o movimento relativo (Le mouvement absolu et le mouvement relatif). A série de artigos, de autêntica natureza historiográfica, é dedicada praticamente em sua inteireza à exposição de concepções reconhecidamente metafísicas sobre a natureza do espaço. Depois de afirmar no primeiro capítulo que a decisão sobre o caráter absoluto do movimento é uma questão metafísica insolúvel do ponto de vista da experiência, Duhem analisará, no restante da série, os diversos argumentos a favor e contra a realidade do espaço absoluto. Por outras palavras, $O$ movimento versa sobre um debate metafísico milenar ausente em Salvar os fenômenos, e deve ser lido como contrapartida a esta última, já que o debate que aqui falta é naquela encontrado. É importante, pois, evitar prolongar o padrão interpretativo encontrado em Salvar os fenômenos e em algumas passagens dos Estudos sobre Leonardo da Vinci para toda a produção duhemiana, uma vez que obras como 0 movimento absoluto, os próprios Estudos e, sobretudo, $O$ sistema do mundo, não podem ser subsumidas no mesmo estilo que caracteriza Salvar os fenômenos. ${ }^{\mathbf{1 7}}$

17 Para uma discussão e classificação pormenorizadas das obras duhemianas, que as distingue em dois grandes gêneros, rotulados como obras "filosófico-históricas", que tendem a tratar a evolução histórica de modo a verificar uma tese metodológica qualquer, e obras essencialmente "historiográficas", que comportam excessos em relação 


\section{O ATOMISMO EM QUESTÃo}

Conhecido como um dos mais ardentes antagonistas do atomismo, Duhem defendia uma concepção teórica de cunho fenomenológico, e seu projeto enquanto físico almejava à unificação da física teórica sobre as bases da termodinâmica. Em virtude da própria natureza conceitual da termodinâmica, opunha-se ele ferrenhamente às teorias atomistas por entender que estas não salvavam adequadamente os fenômenos e, ademais, por localizar a causa dessa insuficiência na pretensão atomística de explicar as aparências por meio de entidades e processos cujas propriedades eram, nos fins do século xIX, muito pouco determinadas. $\mathrm{O}$ atomismo transformava-se então numa aventura metafísica altamente especulativa (cf. Duhem, 1895c, p. 861-5), já que fazia apelo a "qualidades ocultas" essencialmente irredutíveis como princípio para a dedução segura das leis experimentais. Os flagrantes e sucessivos malogros das tentativas de explicação atomista, insistia o crítico, conduziam os adeptos do atomismo à proliferação teórica ou à introdução de hipóteses ad hoc para manter as teorias desmentidas pela experiência já existentes, tornando o mecanismo explicativo destas ainda mais inverossímil. Os riscos do atomismo seriam vários, dentre os quais o erro de tomar por real o que não passaria de um conceito arbitrário, com a decorrente crença de que os constituintes últimos da matéria já nos seriam conhecidos e, de um ângulo mais sociológico, a perda do "consentimento universal" entre os físicos, provocada pelo alto grau de arbitrariedade associado tanto ao estabelecimento das qualidades últimas da matéria quanto à dedução das leis experimentais a partir daquelas qualidades (Teoria, p. 17). Mas é premente ressaltarmos que as críticas duhemianas ao atomismo nos níveis metodológico e teórico não implicam a recusa do reconhecimento histórico da herança positiva dos anseios atomistas. Vejamos isso mais de perto.

Comecemos por reparar uma inexatidão cometida inclusive por aqueles que, como Donald Gillies, observaram que Duhem concedeu à metafísica um papel não meramente nulo ou deletério sobre a física. Após ressaltar que o autor de $A$ teoria física admite que a astrologia tenha contribuído para o advento da gravitação universal, Gillies afirma haver um caso em que nosso autor teria incorrido em sério erro, vale dizer, a defesa de uma visão do atomismo como um estorvo ao progresso científico (Gillies, 1993, p. 198). ${ }^{18}$ Até que ponto seria exato defender essa tese, que já tivera em Agassi um proponente (cf. seção 1)?

àquele objetivo, isto é, que possuem certa autonomia com relação a ele, cf. Leite, 2012, p. 31-51. Consoante essa classificação, Salvar os fenômenos pertenceria ao primeiro gênero, ao passo que $O$ sistema do mundo, excetuados alguns capítulos do segundo volume, os Estudos sobre da Vinci, também com algumas exceções, e O movimento absoluto e o movimento relativo, poderiam ser subsumidos no segundo gênero.

18 "Em termos gerais, Popper e Duhem concordam acerca da influência da metafísica sobre a ciência, mas eles diferem de modo interessante sobre um exemplo particular - aquele do atomismo. Para Popper, o atomismo é um 
Com relação ao fato de Duhem não tratar do atomismo em suas principais obras historiográficas, devemos lembrar, sobretudo, que estas, apesar de cobrirem longos períodos, tinham ora seu termo em Galileu (como nos Estudos), ora em Copérnico (como em $O$ movimento absoluto e, cabe supor, do inacabado Sistema do mundo). O tema (no caso de $O$ movimento absoluto) ou o período (no caso dos Estudos ou do Sistema) analisado nessas obras poderia eximi-lo do estudo aprofundado do atomismo, uma vez que essa teoria, nascida na Grécia antiga, perdeu grande parte de sua influência na Idade Média para ser reavivada, como sabemos, principalmente no século xviı, nas explicações cosmológicas fornecidas por Gassendi, Boyle e Newton, os quais advogavam uma filosofia mecanicista de inspiração corpuscularista. ${ }^{19}$ No entanto, Duhem aceita que as doutrinas atomistas persistiram durante o medievo: "A ideia do átomo jamais foi inteiramente esquecida pelos filósofos cristãos" (Sistema, 3, p. 102). ${ }^{20}$ Guilherme de Conches (século xıI) recebeu, entre suas influências, aquela de Lucrécio (Sistema, 3, p. 88); as obras de Geraldo de Odon (†1349), Roberto Holkot (†1349), Nicolau de Autrecourt (†1369) e, sob uma forma mais sutil, Gilles de Rome (†1316) também atestariam a perseverança atomista (Estudos, 2, p. 10-1). Nicolau Bonet (†134,3), com seu "atomismo integral", também é estudado (Sistema, 7, p. 4,03-12). Além disso, tanto nos Estudos sobre Leonardo da Vinci (2, p. 3-53, 368-4.07) quanto no Sistema do mundo (7, p. 3-88, 89-157), obras que envolvem discussões cosmológicas mais amplas, o autor não deixou de abordar a teoria dos mínimos naturais (minima naturalia), característica da Idade Média. De acordo com John Murdoch (2001, p. 91), o historiador francês foi provavelmente o primeiro a fazê-lo e, não bastasse, embora sua interpretação mereça reparos, afirma o comentador, as análises duhemianas permaneceriam até o início de nosso século, juntamente com aquelas de Anneliese Maier, como uma das melhores já realizadas (2001, p. 93). ${ }^{21}$

Duhem também explorou a escola atomista a partir do século XVII em seus escritos anteriores a 1904, quando ainda não havia se voltado para a filosofia medieval (Duhem, 1892; 1985 [1902]). Dentre as escolas cosmológicas que procuravam explicar

dos mais impressionantes exemplos de como uma teoria metafísica pode ter uma influência benéfica sobre a ciência. Duhem, entretanto, sustenta que a influência do atomismo sobre a ciência foi perniciosa [baleful]" (Gillies, 1993, p. 197).

19 As teses de Lucrécio, ao que tudo indica, foram negligenciadas durante a Idade Média, para voltarem a ser estudadas com bastante atenção apenas no Renascimento (cf. Évora, 1996, p. 36, que segue as conclusões de Cohen e Drabkin; Henry, 2005 [2000], p. 140-1; Ferrater-Mora, 2000).

20 Tese que paulatinamente tem sido aceita e difundida pelos estudiosos. Ver a introdução escrita por Christophe Grellard e Aurélien Robert ao livro por eles editado, com especial destaque para as páginas 4 e 5 (cf. Grellard \& Robert, 2009a, p. 1-14).

21 Julgamento muito parecido, o qual destaca o "pioneirismo" do historiador francês ao relevar a existência de um atomismo no século XIv, é feito por De Boer (2009, p. 86). 
os fenômenos através de sua essência a escola atomista é sempre citada (Duhem, 1903b, p. 20-4; Teoria, p. 14- - ). Se ele virá a minimizar a importância do atomismo na formulação dos princípios das ciências do equilíbrio e do movimento em sua Notice (Duhem, 1917, p. 169), isso não o impede de reconhecer a origem metafísica da notação química moderna, área para a qual o atomismo contribuiu de maneira fundamental:

Entretanto, se bem que nós não tenhamos invocado nem o nome, nem a ideia de átomo na teoria que nós acabamos de desenvolver, é, na realidade, em meio às hipóteses sobre a constituição atômica da matéria que esta teoria foi constituída (Duhem, 1892, p. 439; grifos meus; cf. Duhem, 1985 [1902], p. 133).

A própria nomenclatura da "notação atômica" de fins do século xIx exibe sua ascendência atomista (Duhem, 1892, p. 4.55). Urgia dar livre curso a um ambicioso projeto de depuração do conceito de átomo na química. Duhem esperava que esta ciência, em seu estágio avançado, se desfizesse da herança atomista para manter-se ligada tão somente à notação química, sem a suposição, dentre outras tantas, de que os símbolos químicos e suas regras de combinação correspondessem a algo de real (Duhem, 190ob, p. 16). A depuração que nosso autor pretende operar na notação química em "Notação atômica e hipóteses atomistas" segue estreito paralelo com outra, idealizada na mesma época, em "Fragmentos de um curso de óptica" (Duhem, 1894, 1895a, 1896a). Logo no início do primeiro artigo do curso, vemo-lo repetir o procedimento costumeiro de traçar a gênese das ideias que influíram, neste caso, no advento da óptica física: "A óptica física nasceu da ideia cartesiana segundo a qual a luz consiste em movimentos muito rápidos de um corpo especial, o éter" (Duhem, 1894, p. 95). Num primeiro momento, positivo, a óptica vem ao mundo impulsionada por uma ideia essencialmente metafísica, a noção cartesiana de éter; entrementes, continua Duhem, com o passar do tempo, a teoria óptica acaba encontrando dificuldades inevitáveis em função da natureza mecânica paulatinamente assumida por ela e aceita doravante como um dogma. Diante da constatação histórica dessa subordinação, é hora de introduzir uma mudança de orientação: “(...) parece que chegou o momento, para a óptica, de se liberar das hipóteses sobre a natureza da luz, de imitar a termodinâmica que, pouco a pouco, abandonou a teoria mecânica do calor" (Duhem, 1894, p. 95). Tal qual o calor, também a luz necessita ser definida como uma qualidade física irredutível ao movimento de pequenas partes da matéria (cf. Duhem, 1894, p. 96; 1895a, p. 28-9; 1896a, p. 105). Trata-se de mais uma ocorrência em que o mecanicismo deve ceder espaço às teorias de gênero fenomenológico. $\mathrm{O}$ desenvolvimento histórico da termodinâmica serve de modelo para o desenvolvimento das demais teorias. E é grande o esforço contido nas dezenas de páginas que compõem os "Fragmentos" no intuito de construir uma teoria óptica logi- 
camente independente da metafísica. Ora, o que explica esse projeto de eliminação dos resquícios metafísicos recalcitrantes nas teorias mecânicas da época senão o duplo reconhecimento de sua existência e do apego dos cientistas à metafísica? Esse projeto de depuração não faria qualquer sentido se o seu proponente não atentasse para os elementos metafísicos presentas naquelas teorias.

\section{OBservaÇÕes Gerais E GONGLUSÕes}

A perfeita compreensão de uma teoria e do seu valor de saber requer a história externa a ela ou o quase sempre inescrutável exame dos pensamentos mais íntimos do cientista. É o que temos visto ao longo das páginas precedentes. Uma teoria não pode ser devidamente compreendida em seu significado se não a vincularmos à sua gênese histórica e, se possível, psicológica. Como sabemos, esse tipo de abordagem ganhou destaque na filosofia da ciência na segunda metade do século xx. As longas discussões metafísicas que agitaram o medievo descritas nas obras historiográficas duhemianas não são gratuitas, elas estão lá em função de uma necessidade de contextualização do nascimento da ciência moderna, ocorrido em um meio repleto de discussões teológicas e filosóficas em que a preocupação científica era apenas secundária. Se a ciência moderna nasceu foi graças a uma revolução teológico-metafísica, a um sílabo imposto de fora. Duhem não possui, percebe-se sem maiores dificuldades, uma concepção estritamente normativa da ciência; ele busca justificar historicamente tanto a sua metodologia quanto o seu projeto científicos, sempre tendo em vista a ciência como ela é ou foi praticada, de sorte que não há prejuízo dos elementos metafísicos em suas descrições. Ao exaltar os benefícios científicos oriundos das especulações metafísicas e o valor da versão histórica dos problemas teórico-metodológicos, o pensamento do professor de Bordeaux é como que confirmado pela "virada histórica" em curso na década de 1960. Fica demonstrado, com o peso dos numerosos exemplos aqui expostos, que sua historiografia está assaz distante de uma reconstrução cujo objetivo primevo seja o de pinçar casos históricos nos quais a metafísica tenha atuado pura e negativamente como obstáculo à evolução das teorias.

Por fim, uma última observação crítica a ser feita. Fiel à linhagem dos filósofos da ciência do "círculo de Popper", John Watkins (1975, p. 91) não incluiu Duhem no rol dos historiadores que, como Meyerson, Burtt e Koyré, destacaram o subsídio metafísico no avanço do conhecimento científico e cooperaram de alguma maneira para a reaporximação entre a metodologia e a história da ciência. Sem dúvida, uma omissão que merece ser citada. Como seus colegas, Watkins não demonstra qualquer conhecimento das obras historiográficas duhemianas e, uma segunda vez com eles, sua leitura 
ampara-se integralmente na Teoria física. O maior problema da interpretação do filósofo inglês começa páginas depois. Ao discordar da visão popperiana segundo a qual somente em sua "infância" a ciência teria necessitado de uma "inspiração metafísica", ele associa a Popper o nome de Duhem, supostamente defensor de uma posição semelhante (Watkins, 1975, p. 106). Por ter lido A teoria física, Watkins sabe, com as limitações inerentes impostas pela natureza filosófica dessa obra, que a concepção histórica de nosso autor é plenamente compatível com a tese de que as especulações metafísicas exerceram no passado alguma influência favorável na evolução das teorias físicas. Só que, também em A teoria física, o projeto de eliminação do conteúdo metafísico das teorias é retomado, de modo que as teorias maduras devem ser independentes dos "sistemas metafísicos" (Watkins, 1975, p. 106). Isso nos basta para que possamos inserir aqui duas notas. Watkins está correto ao dizer que os sistemas metafísicos não devem mais, para Duhem, exercer alguma influência direta sobre as teorias físicas, cuja autonomia é reivindicada; não nos parece certo, porém, quando sugere que a inspiração metafísica só tenha tido um efeito positivo na infância da ciência, e que ela deveria ser de algum modo abandonada. Duhem jamais rejeitou a "inspiração metafísica" que move os físicos em seu trabalho (cf. seção 2); suas críticas dirigem-se principalmente aos "sistemas metafísicos" influentes, que não devem ser confundidos com aquela inspiração. Qual seja a posição de Popper não nos interessa aqui, mas o uso inadvertido das expressões "inspiração metafísica" e "sistemas metafísicos" pode conduzir o leitor à má compreensão do pensamento do autor de "Física e metafísica", ensaio no qual os sistemas metafísicos são definidos como "um conjunto de juízos positivos" que "propõem uma definição da natureza das coisas mais detalhada, mais determinada", com a finalidade de deduzir consequências observáveis (cf. FisMet, p. 44-5). A ressalva à metafísica que é constante sob a pena de duhemiana concerne especialmente às hipóteses cosmológicas determinadas, a saber, àquelas hipóteses de cujo conteúdo alguma consequência empírica pode ser derivada. São as hipóteses sobre a natureza íntima da matéria o alvo de suas censuras, são elas que criam o dissenso entre os físicos e que devem ser evitadas. Mas a inspiração metafísica que move o físico na busca da verdade, dir-se-ia, da "classificação natural" (pois a verdade é o objetivo das teorias físicas; cf. Leite, 2007, p. 230-50), jamais é negada ou rechaçada por Duhem. A crença em uma "ordem supereminente" e a "adivinhação" ou "suspeita" de que nossas teorias bem sucedidas se aproximam daquela ordem não podem ser demonstradas logicamente, muito embora elas nos sejam naturais ou inevitáveis (cf. Duhem, 1908, p. 18); sem elas, a própria física teórica, enquanto distinta da engenharia aplicada, deixaria de fazer sentido (Duhem, 1899, p. 389-90; 1900a, p. 251), pressuposto que nenhum método científico traz consigo sua "plena e inteira justificação" (Duhem, 1981 [1905], p. 445). Na teoria da ciência duhemiana, o próprio princípio unificacionista, a pre- 
tensão de construir uma física unitária, coerente e que represente todos os fenômenos observados através de uma única teoria logicamente ordenada, é um postulado metafísico. Daí que a justificação mesma da termodinâmica, teoria que serve de alicerce para a unificação da física teórica tão almejada por ele, encontre suas razões na metafísica. E dessas crenças gerais a física não pode e nem deve ser depurada, sob o risco de ser extinta.@

\title{
Fábio Rodrigo Leite
}

Doutor pelo Departamento de Filosofia, Faculdade de Filosofia, Letras e Ciências Humanas, Universidade de São Paulo, Brasil. efferrelle@yahoo.com.br

\section{On the historical relations between physics and metaphysics in Pierre Duhem's work}

\begin{abstract}
In this article, we aim to show, by means of several examples, that Pierre Duhem's logical distinction operated by Pierre Duhem between physics and metaphysics does not prevent him, from a historical perspective, recognizing that there can be a fruitful interplay between the two fields of knowledge. We distinguish three possible levels of interaction that we believe Duhem accepts between physics and metaphysics: (a) that the physicist works constantly moved by metaphysical ambitions not authorized by rigorous logic; (b) that the metaphysical systems have contributed to the progress of many physical theories and, especially, to the birth of modern science, and; (c) that we can identify long-lasting metaphysical traditions of research which have shown themselves to be more fertile than the positivist traditions.
\end{abstract}

KeYwords $\bullet$ Duhem. Physics. Metaphysics. Methodology. History of science. Historiography.

\section{REFERÊNGIAS BIBLIOGRÁFIGAS}

Agassi, J. Duhem versus Galileo. The British Journal for the Philosophy of Science, 8, 31, p. 237-48, 1957.

Towards a historiography of science. History and Theory Studies in the Philosophy of History, 2, 2.

Haia: Wesleyan Press, 1963.

Ariew, R. \& Barker, P. (Ed.). Essays in the history and philosophy of science. Indianapolis: Hackett, 1996. Brenner, A. Duhem: science, réalité et apparence. Paris: Vrin, 1990.

. Genèse, évolution et continuité du développement scientifique selon Pierre Duhem. Revue des

Questions Scientifiques, 175, 1, p. 37-58, 2004.

Bulliot, J. Jean Buridan et le mouvement de la Terre: Question 22 du second livre du 'De coelo'. Revue de Philosophie, 14, 25, p. 5-24, 1914 .

Claagett, M. Le système du monde, v. 6-7. Isis, 49, 3, p. 359-62, 1958. 
De Boer, S. The importance of atomism in the philosophy of Gerard of Odo. In: Grellard, C. \& Robert, A. (Ed.). Atomism in late medieval philosophy and theology. Leiden/Boston: Brill, 2009. p. 85-106.

Duнem, P. Notation atomique et hypothèses atomistiques. Revue des Questions Scientifiques, 31, p. 391$454,1892$.

. Une nouvelle théorie du monde inorganique. Revue des Questions Scientifiques, 33, p. 99-133, 1893.

. Fragments d'un cours d'optique 1. Annales de la Société Scientifique de Bruxelles, 18, p. 95-123, 1894.

. Fragments d'un cours d'optique 2. Annales de la Société Scientifique de Bruxelles, 19, p. 27-94, 1895 a.

. Les théories de la chaleur. Revue des Deux Mondes, 4, 13o, p. 380-415, 1895b.

. Les théories de la chaleur. Revue des Deux Mondes, 4, 13o, p. 851-68, 1895c.

. Fragments d'un cours d'optique 3. Annales de la Société Scientifique de Bruxelles, 20, p. 27-105, $1896 \mathrm{a}$. . L'évolution des théories physiques du xvıre siècle jusqu'à nos jours. Revue des Questions Scientifiques, 4. , p. 463-99, 1896b.

. La loi des phases: à propos d'un livre récent de M. Wilder D. Bancroft. Revue des Questions Scientifiques, 44, p. 54-82, 1898 .

. Usines et laboratoires. Revue Philomatique de Bordeaux et du Sud-Ouest, 2, 9, p. 385-4,00, 1899.

. Théorie et pratique. Revue Philomathique de Bordeaux et du Sud-Ouest, 3, 6, p. 250-62, 1900 .

L'oeuvre de M. J. H. van't Hoff: À propos d'un livre récent. Revue des Questions Scientifiques, 47,

p. $5^{-27}, 1900 \mathrm{~b}$.

Les théories électriques de J. Clerk Maxwell: Étude historique et critique. Paris: Hermann, 1902.

. Analyse de l'ouvrage de Ernst Mach: 'La mécanique'. Bulletin des Sciences Mathématiques, 27, p.

261-83, 1903a.

L'évolution de la mécanique. Paris: A. Joanin, 1903b.

De l'accélération produite par une force constante: Notes pour servir à l'histoire de la dynamique.

In: Ciaperède, E. (Ed.). Compte Rendu du Congrès Internationale de Philosophie, II, 1904. p. 859-915.

. Paul Tannery. Revue de Philosophie, 5, 1, p. 216-3o, 1905.

Les origines de la statique. Paris: Hermann, 1905-1906. 2v. (Origens)

Josiah-Willard Gibbs: À propos de la publication de ses 'Mémoires scientifiques'. Bulletin des Sciences

Mathématiques, 31, p. 181-211, 1907 .

. La valeur de la théorie physique. Revue Générale des Sciences Pures et Appliquées, 19, 1, p. 7-19, 1908. Le mouvement absolu et le mouvement relatif. Montligeon: Librairie de Montligeon, 1909.

Traité dénergétique ou de thermodynamique générale. Paris: Gauthier-Villars, 1911. 2v.

Quelques réflexions sur la science allemande. In: . La science allemande. Paris: Hermann, 1915.

p. 101-4.3.

. Notice sur les titres et travaux scientifiques de Pierre Duhem. Paris: Gauthier-Villars, 1917.

. Le système du monde: histoire des doctrines cosmologiques de Platon a Copernic. Paris: Hermann, 1954-

1959 [1913-1959]. 10v. (Sistema)

Physique de croyant. In:

La théorie physique: Son objet et sa structure. 3 ed. Paris: Vrin, 1981

[1905] p. 4,13-72.

. La théorie physique: Son objet et sa structure. 3 ed. Paris: Vrin, 1981 [1906]. (Teoria)

. Études sur Léonard de Vinci: Ceux qu'il a lus et ceux qui l'ont lu. Paris: Archives Contemporaines, 1984a [1906-1913].3v. (Estudos)

. Salvar os fenômenos. Ensaio sobre a noção de teoria física de Platão a Galileu. Cadernos de História e Filosofia da Ciência, 3, 1984, [1908].

Le mixte et la combinaison chimique: Essai sur l'évolution d'une idée. Paris: Fayard, 1985 [1902].

. Algumas reflexões sobre as teorias físicas. Ciência e Filosofia, 4, p. 13-37, 1989a [1892]. (Reflexões)

. Física e metafísica. Ciência e Filosofia, 4, p. 41-59, 1989b [1893]. (FisMet)

A escola inglesa e as teorias físicas. Ciência e Filosofia, 4, p. 63-84, 1989c [1893]. 
Dunem, P. Algumas reflexões acerca da física experimental. Ciência e Filosofia, 4, p. 87-118, 1989d [1894]. History of physics. In: ArIEw, R. \& BARKer, P. (Ed.). Essays in the history and philosophy of science. Indianapolis: Hackett, 1996 [1911]. p. 163-221.

Évora, F. (Ed.). Ciência no século xix. Campinas: CLE/Unicamp, 1994. . A evolução do conceito de inércia: De Philoponos a Galileo. São Paulo, 1996. Tese (Doutorado em Filosofia). Faculdade de Filosofia, Letras e Ciências Humanas, Universidade de São Paulo.

Ferrater-Mora, J. Atomismo. In: Dicionário de filosofia. São Paulo: Edições Loyola, 2000. v. 1, p. 221-4.

Gilles, D. Philosophy of science in the twentieth century: four central themes. Oxford/Cambridge: Blackwell, 1993.

Grellard, C. \& Robert, A. (Ed.). Atomism in late medieval philosophy and theology. Leiden/Boston: Brill, 2009.

. \& Introduction. In: \& (Ed.). Atomism in late medieval philosophy and theology. Leiden/Boston: Brill, 2009a. p. 1-14.

Henry, J. Atomism. In: Ferngren, G. B. (Ed.). The history of science and religion in the western tradition: An encyclopedia. New York/London: Garland, 2005 [2000]. p. 139-45.

Lakatos, I. O falseamento e a metodologia dos programas de pesquisa científica. In: LaKatos, I. \& Musgrave, A. (Org.). A crítica e o desenvolvimento do conhecimento. São Paulo: Cultrix, 1979. p. 109-243.

. La historia de la ciencia y sus reconstrucciones racionales. In: Worrall, J. \& Currie, G. La metodologia de los programas de investigación científica. Madrid: Alianza Universidad, 1989. p. 134-79.

Lakatos, I. \& Musgrave, A. (Org.). A crítica e o desenvolvimento do conhecimento. São Paulo: Cultrix, 1979. Leite, F. R. A metodologia do senso comum: Um estudo da metodologia científica de Pierre Duhem. São Paulo, 2007. Dissertação (Mestrado em Filosofia). Faculdade de Filosofia, Letras e Ciências Humanas, Universidade de São Paulo.

Um estudo sobre a filosofia da história e sobre a historiografia da ciência de Pierre Duhem. São Paulo, 2012. Tese (Doutorado em Filosofia). Faculdade de Filosofia, Letras e Ciências Humanas, Universidade de São Paulo.

Lüthy, C. \& Murdoch, J. (Ed.). Late medieval and early modern corpuscularmatter theories. Leiden/Boston: Brill, 2001.

МАсн, E. The science of mechanics: A critical and historical account of its development. Illinois: Open Court, 1960.

Матоссні, R. Chimica e filosofia: scienza, epistemologia, storia e religione nell'opera di Pierre Duhem. Firenze: La Nuova Italia, 1985 .

Mariconda, P. Duhem e Galileu: Uma reavaliação da leitura duhemiana de Galileu. In: Évora, F. (Ed.). Ciência no século xix. Campinas: CLE/Unicamp, 1994. p. 123-6o.

Martin, R. N. The genesis of a mediaeval historian: Pierre Duhem and the origin of statics. Annals of Science, 33, p. 119-29, 1976.

. Pierre Duhem: philosophy and history in the work of a believing physicist. La Salle: Open Court, 1991.

Martins, R.Ainfluência de Aristóteles na obra astrológica de Ptolomeu (o Tetrabiblos). Trans/Form/Ação, $18, \mathrm{p} \cdot 5^{1^{-}} 7^{8}, 1995$.

Murdoch, J. The medieval and renaissence tradition of minima naturalia. In: Lüthy, C. \& Murdoch, J. (Ed.). Late medieval and earlymodern corpuscularmatter theories. Leiden/Boston: Brill, 2001. p. 91-131.

WATkins, J. Metaphysics and the advancement of science. The British Journal for the Philosophy of Science, 26, 2, p. 91-121, 1975.

Worrall, J. \& Currie, G. La metodologia de los programas de investigación científica. Madrid: Alianza Universidad, 1989. 